Note

\section{An Improved Method for the Preparation of Phenyl $\alpha$-L-Arabinofuranoside and Its Isomers}

\author{
Kazuaki Higashi, Hiroshi Hori, * \\ Tadayuki IshIYAma and Yoichiro Окімото
}

\author{
Department of Agricultural Chemistry, \\ Faculty of Agriculture, Tamagawa University, \\ Machida-shi, Tokyo 194, Japan
}

Isao KUSAKABE and Tsuneo YASUI

Institute of Applied Biochemistry, The University of Tsukuba, Ibaraki 305, Japan

Received August 23, 1982

Phenyl glycosides are generally used as substrates to determine the enzyme activity and kinetic parameters or to study the substrate specificity of glycosidases. For instance, Tsujisaka ${ }^{1}{ }^{1}$ and Chiba and Shimomura ${ }^{2)}$ have compared in detail substrate specificity and kinetic parameters of various $\alpha$-glucosidases, using phenyl $\alpha$-Dglucoside and a series of malto-oligosaccharides, and classified the enzymes according to these results.

In $\alpha$-L-arabinofuranosidases (AFase), however, there have been only a few reports studying the substrate specificity or kinetic parameters ${ }^{3 \sim 5}$ in comparison with other glycosidases. The difficulty of a detail study on substrate specificity or kinetic parameters seems to be one reason why $\mathrm{P} \alpha \mathrm{LAF}$ is not commercially available and why preparation of $\mathrm{P} \alpha \mathrm{LAF}$ or arabino-oligosaccharides is not particularly easy.

$\mathrm{P} \alpha \mathrm{LAF}$ is generally synthesized according to the method reported by Börjeson et al. ${ }^{6}$ which is a preferential method for the synthesis of $\mathrm{P} \alpha \mathrm{LAF}$ of $\mathrm{mp} 63 \sim 66^{\circ} \mathrm{C},[\alpha]_{\mathrm{D}}-159^{\circ}$ ( $c=2.0$, water), Found $\mathrm{C}, 58.1 ; \mathrm{H}, 6.19 ; \mathrm{O}, 35.5, \mathrm{C}_{11} \mathrm{H}_{14} \mathrm{O}_{5}$ requires $\mathrm{C}, 58.4 ; \mathrm{H}, 6.24 ; \mathrm{O}, 35.4 \%$. Many researchers have synthesized $\mathrm{P} \alpha \mathrm{LAF}$ by this method, but presented no data for the purity or the structural confirmation of P $\alpha$ LAF.

This paper deals with a modification of the method of Börjeson et al. and the isolation of P $\alpha \mathrm{LAF}$ by the method of Austin et al. ${ }^{\text {) }}$

\section{EXPERIMENTAL}

General method. Gas liquid chromatography was performed by a Shimadzu GC-6A gas chromatograph with a glass column $(3 \mathrm{~mm} \times 1.5 \mathrm{~m})$ packed with $3 \%$ ECNSS on Gas Chrome Q. Methylation analysis was carried out by the method of Hakomori, ${ }^{8)}$ and methylated arabinitol acetate was analyzed with a Shimadzu GCMS 7000. IR spectra were recorded with a Shimadzu IR-420 Spectrophotometer and optical rotations were determined with a JASCO DIP-140 Digital polarimeter. Elementary analysis was performed by the Chemical Analysis Center of The University of Tsukuba.

1,2,3,5-Tetra-O-acetyl-L-arabinofuranose (I). To a solution of L-arabinose $(50 \mathrm{~g})$ in DMF were added acetic anhydride $(125 \mathrm{ml})$ and pyridine $(100 \mathrm{ml})$, and the mixture was heated for $50 \mathrm{hr}$ at $50^{\circ} \mathrm{C}$. The reaction mixture was poured into ice-cooled water $(2500 \mathrm{ml})$, extracted with chloroform $(3 \times 250 \mathrm{ml})$, and the extract concentrated to a syrup. This syrup was dissolved in carbon tetrachloride $(700 \mathrm{ml})$, washed with water $(2 \times 100 \mathrm{ml})$, dried with anhydrous magnesium sulfate, and further concentrated to a syrup. This syrup was then applied to a column of silica gel $(2 \times 50 \mathrm{~cm})$, and chromatographed with a solvent system of ethyl acetate-chloroform $(1: 1, \mathrm{v} / \mathrm{v})$. The fractions containing sugars were collected and concentrated to a syrup.

In this mild condition, the yield of acetylated arabinose was not decreased, and there was no difference in the ratio

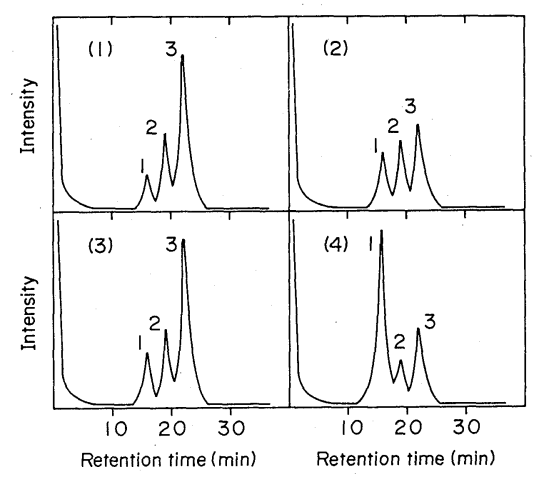

FIG. 1. Gas Liquid Chromatography of Acetylated Arabinose.

A series with DMF: (1) $150^{\circ} \mathrm{C}$ for $5 \mathrm{~min}$. (3) $50^{\circ} \mathrm{C}$ for $50 \mathrm{hr}$. A series without DMF: (2) $150^{\circ} \mathrm{C}$ for 5 min. (4) $50^{\circ} \mathrm{C}$ for $50 \mathrm{hr}$. Peak 1, 1,2,3,4-tetra- $O$-acetyl L-arabinopyranose; peaks 2 and 3, 1,2,3,5-tetra- $O$-acetyl $\mathrm{L}$-arabinofuranose.

* Present address: Department of Agricultural Chemistry, Faculty of Agriculture, Shizuoka University, Shizuoka 420, Japan.

Abbreviations: AFase, $\alpha$-L-arabinofuranosidase; P $\alpha \mathrm{LAF}$, phenyl $\alpha$-L-arabinofuranoside; P $\beta \mathrm{LAF}$, phenyl $\beta$-Larabinofuranoside; P $\alpha \mathrm{LAP}$, phenyl $\alpha$-L-arabinopyranoside; $\mathrm{P} \beta \mathrm{LAP}$, phenyl $\beta$-L-arabinopyranoside; DMF, $N, N$ dimethylformamide. 
of arabinofuranose tetraacetate, peaks 2 and 3, as determined by GLC and GCMS and shown in Fig. 1. Furthermore, the production of colored materials was reduced. From L-arabinose $(50 \mathrm{~g}), 85 \mathrm{~g}$ of (I) was yielded as a pale yellow syrup $(89.1 \%)$.

Phenyl 2,3,5-tri-O-acetyl- $\alpha$-L-arabinofuranoside (II). The whole amount of (I) was mixed with phenol (100 g). $p$ Toluenesulfonic acid $(0.8 \mathrm{~g})$ was added as a catalyst, and the mixture heated at $100^{\circ} \mathrm{C}$ for $25 \mathrm{~min}$ under reduced pressure. Benzene $(600 \mathrm{ml})$ was added to the reaction mixture, which was then washed with $1 \mathrm{~N}$ sodium hydroxide $(6 \times 40 \mathrm{ml})$, washed with water (until neutral $\mathrm{pH})$, dried with anhydrous magnesium sulfate, and concentrated to a syrup. In this step, $61 \mathrm{~g}$ of (II) was synthesized $(64.8 \%)$.

Phenyl $\alpha$-L-arabinofuranoside (P $\alpha \mathrm{LAF})$. The whole amount of (II) was dissolved in dry methanol $(1500 \mathrm{ml})$ and sodium methoxide $(1.5 \mathrm{~g})$ added. After standing for $3 \mathrm{hr}$ at room temperature, the reaction mixture was concentrated to a syrup, dissolved in water $(100 \mathrm{ml})$, desalted with Dowex 50, and concentrated to a small volume. The concentrate was washed with chloroform $(3 \times 25 \mathrm{ml})$, extracted with ethyl acetate $(8 \times 100 \mathrm{ml})$, and concentrated to a syrup. This syrup was decolorized by silica gel column chromatography as described above, and the fractions containing sugars were collected, and concentrated to a syrup. In this step, $8.4 \mathrm{~g}$ of P $\alpha \mathrm{LAF}$ was yielded as a colorless syrup $(21.5 \%)$.

Isolation of the major component $C$. The resulting colorless syrup of $\mathrm{P} \alpha \mathrm{LAF}$ contained a major component $\mathrm{C}$ and three minor components A, B and D as shown in the GLC data (Fig. 2-1). Isolation of component $C$ was performed according to the method of Austin et al. A column of Dowex $1 \times 2$ (free base, $2 \times 50 \mathrm{~cm}$ ) was activated with $0.5 \mathrm{~N}$ sodium hydroxide, and washed with distilled water (free from carbon dioxide). One and half grams of the colorless syrup was applied to this column and chromatographed with distilled water (free from carbon dioxide). The phenyl L-arabinoside in each fraction was monitored by the measurement of absorbance at $266 \mathrm{~nm}$, and also checked by GLC. As shown in Fig. 3, two fractions (Fr-I and Fr-II) were obtained; Fr-II contained only component C (1.0 g), which was identified as P $\alpha \mathrm{LAF}$, and Fr-I was a mixture of components A, B and D (Figs. 2-2 and 2-3).

Fractionation of the minor components $A, B$ and $D$. The sample, Fr-I (1.96 g) was applied to a column of silica gel $(2 \times 50 \mathrm{~cm})$, which was previously equilibrated with ethyl acetate, chromatographed with the same solvent, and fractionated. As shown in Fig. 4, three fractions (Peaks 1, 2 and 3) were obtained. Peak 1 contained only component $B$, and peak 2 contained component $D$ with a trace amount of components A and B. Rechromatography on the silica gel column with the same procedure, and crystal-

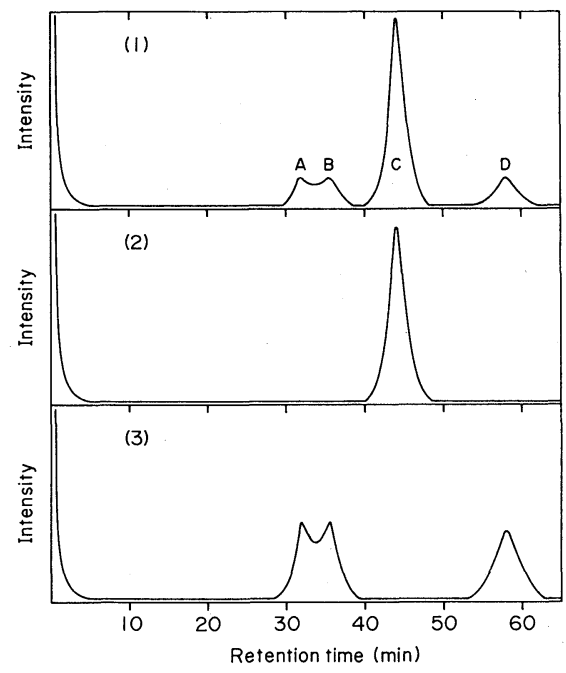

FIG. 2. Gas Liquid Chromatography of Phenyl LArabinosides.

(1) Synthesized phenyl L-arabinosides mixture; (2) Fr-lI on Dowex 1 column chromatography; (3) Fr-I on Dowex 1 column chromatography.

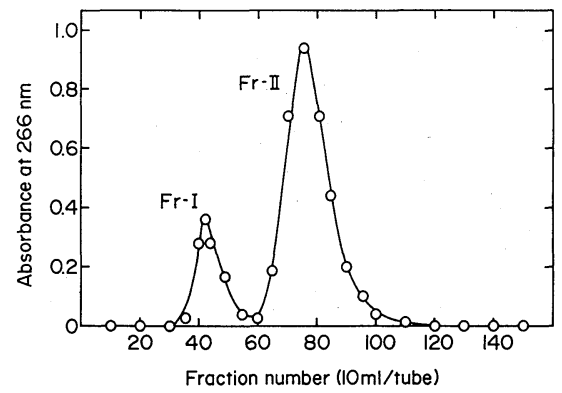

FIG. 3. Column Chromatography of Phenyl LArabinosides Mixture on Dowex 1.

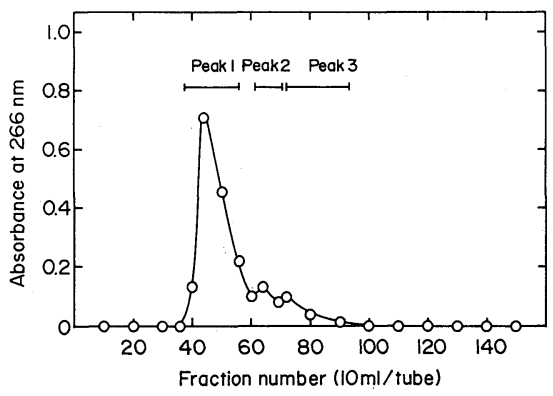

FIG. 4. Column Chromatography of Phenyl LArabinosides Mixture on Silica Gel.

lization of these two fractions gave components B and D as pure materials, but component A could not be successfully isolated. 
Component $C(\mathrm{P} \alpha \mathrm{LAF})$. Colorless syrup, $[\alpha]_{\mathrm{D}}^{20}-144^{\circ}$ $(c=0.85$, water). Methylation analysis gave 1,4-di- $O$ acetyl-2,3,5-tri- $O$-methyl arabinitol. IR $v_{\max }^{\mathrm{KBr}} \mathrm{cm}^{-1}: 690$, 750,1220 (; C-O-C'), 1490, 1590, $1600(-), 3320$ (-OH). GC-MS $m / z: 43$ ( $\left.\mathrm{H}_{3} \mathrm{C}-\mathrm{C} \equiv \stackrel{+}{\mathrm{O}}\right), 94$ ( 139, 199, $259\left(\mathrm{M}^{+}-94\right), 279\left(\mathrm{M}^{+}-\mathrm{CH}_{2}-\mathrm{O}-\mathrm{CO}-\mathrm{CH}_{3}\right)$. Anal., Found: C, 58.25; H, 6.19; O, 35.56, Calcd. for $\mathrm{C}_{11} \mathrm{H}_{14} \mathrm{O}_{5}: \mathrm{C}, 58.40 ; \mathrm{H}, 6.23 ; \mathrm{O}, 35.37 \%$.

Component $B(\mathrm{P} \beta \mathrm{LAF})$. White needles, $\mathrm{mp} 82 \sim 85^{\circ} \mathrm{C}$, $[\alpha]_{\mathrm{D}}^{20}+148^{\circ}(c=0.99$, water $)$. Methylation analysis gave 1,4-di- $O$-acetyl-2,3,5-tri- $O$-methyl arabinitol. IR $v_{\max }^{\mathrm{KBr}}$ $\mathrm{cm}^{-1}:$ 690, 750, $1220\left(-\mathrm{C}-\mathrm{O}-\mathrm{C}_{\backslash}^{\prime \prime}\right), 1490,1590,1600$ $(-Q), 3320$ (-OH). GC-MS $m / z: 43 \quad\left(\mathrm{H}_{3} \mathrm{C}-\mathrm{C} \equiv \stackrel{+}{\mathrm{O}}\right)$, 94 ( -ÖH), 97, 139, 199, $259\left(\mathrm{M}^{+}-94\right), 279\left(\mathrm{M}^{+}\right.$ $-\mathrm{CH}_{2}-\mathrm{O}-\mathrm{CO}-\mathrm{CH}_{3}$ ). Anal., Found: C, 58.23; H, 6.24; $\mathrm{O}, 35.53$, Calcd. for $\mathrm{C}_{11} \mathrm{H}_{14} \mathrm{O}_{5}: \mathrm{C}, 58.40 ; \mathrm{H}, 6.23 ; \mathrm{O}$, $35.37 \%$.

Component $D(\mathrm{P} \alpha \mathrm{LAP})$. White needles, $\mathrm{mp} 158^{\circ} \mathrm{C},[\alpha]_{\mathrm{D}}^{20}$ $+8.8^{\circ}(c=0.67$, water). Methylation analysis gave 1,5 -di$O$-acetyl-2,3,4-tri- $O$-methyl arabinitol. IR $v_{\max }^{\mathrm{KBr}} \mathrm{cm}^{-1}: 690$, $750,1220(-\mathrm{C}-\mathrm{O}-\mathrm{C} \backslash), 1490,1590,1600(-2300$ (-OH). GC-MS $m / z: 43$ ( $\left.\mathrm{H}_{3} \mathrm{C}-\mathrm{C} \equiv \stackrel{+}{\mathrm{O}}\right), 94$ ( $\left.-\mathrm{OH}\right), 97$, 139, 199, $259\left(\mathbf{M}^{+}\right.$-94). Anal., Found: C, 58.21; H, 6.21; $\mathrm{O}, 35.58$, Calcd. for $\mathrm{C}_{11} \mathrm{H}_{14} \mathrm{O}_{5}: \mathrm{C}, 58.40 ; \mathrm{H}, 6.23 ; \mathrm{O}$, $35.37 \%$.
P $\beta L A P$ (commercial product). White needles, $\mathrm{mp}$ $173 \sim 175^{\circ} \mathrm{C},[\alpha]_{\mathrm{D}}^{20}+246^{\circ}(c=0.51$, water $)$. Methylation analysis gave 1,5-di- $O$-acetyl-2,3,4-tri- $O$-methyl arabinitol. IR $v_{\max }^{\mathrm{KBr}} \mathrm{cm}^{-1}: 690,755,1220(-\mathrm{C}-\mathrm{O}-\mathrm{C} /), 1480$, 1590, $1600(-2), 3400(-\mathrm{OH})$. GC-MS m/z: $43\left(\mathrm{H}_{3} \mathrm{C}-\right.$ $\mathrm{C} \equiv \stackrel{+}{\mathrm{O}}), 94$ ( Anal., Found: $\mathrm{C}, 58.21 ; \mathrm{H}, 6.21 ; \mathrm{O}, 35.58$, Calcd. for $\mathrm{C}_{11} \mathrm{H}_{14} \mathrm{O}_{5}$ : C, 58.40; $\mathrm{H}, 6.23 ; \mathrm{O}, 35.37 \%$.

\section{REFERENCES}

1) Y. Tsujisaka, J. Jpn. Soc. Starch Sci., 25, 100 (1978).

2) S. Chiba and T. Shimomura, J. Jpn. Soc. Starch Sci., 25, 105 (1978).

3) A. Kaji, K. Tagawa and K. Matsubara, Agric. Biol. Chem., 31, 1023 (1967).

4) A. Kaji and O. Yoshihara, Biochim. Biophys. Acta, 250, 367 (1971).

5) A. Kaji, M. Sato and Y. Tsutsui, Agric. Biol. Chem., 45, 925 (1981).

6) H. Börjeson, P. Jerkman and B. Lindberg, Acta Chem. Scand., 17, 1705 (1963).

7) P. W. Austin, F. E. Hardy, J. G. Buchanan and J. Baddiley, J. Chem. Soc., 5350 (1963).

8) S.. Hakomori, J. Biochem., 25, 205 (1964). 